\title{
Effect of mulching, hydrogel and nutrient management on productivity of summer groundnut
}

\section{H. PATRO AND M. RAY}

Article Chronicle: Received: 08.11.2016;

Revised :

14.11.2016;

Accepted :

25.11.2016

Key Words :

Mulching, hydrogel, Nutrient management, Groundnut
ABSTRACT : A field experiment was conducted at the AICRP on Groundnut, Bhubaneswar Centre of Orissa University of Agriculture and Technology, Bhubaneswar during Rabi-Summer,2013-14 in a split-plot design with three replications two mulching practices (With biodegradable mulch and Without biodegradable mulch) in the main plot sown with three hydrogel levels (Control(Irrigation as per recommendation), - $2.5 \mathrm{~kg} / \mathrm{ha}$ (reduce 2-3 irrigation depending on location and $5.0 \mathrm{~kg} / \mathrm{ha}$ (reduce 2-3 irrigation depending on location)in the sub plots and three levels of Nutrient management practices (Organic nutrient management(locally available resources), Inorganic nutrient management and Integrated nutrient management in sub sub plots. Pod yield (2104 kg/ha), haulm yield(4025 kg/ha), nodules/plant (40.3), shelling per cent (68.9\%), hundred kernel weight (40.2g), B:C ratio (2.11) and r net monetary returns (Rs.43172/ha) were obtained with biodegradable mulch which was significantly higher than practice without mulching ( $1650 \mathrm{~kg} / \mathrm{ha}, 3276 \mathrm{~kg} / \mathrm{ha}, 34,63.2 \%, 32.7 \mathrm{~g}, 1.66$ and Rs. 25499/ ha), respectively. Application of hydrogel @ $5.0 \mathrm{~kg} / \mathrm{ha}$ to groundnut also significantly influenced pod yield of groundnut $(2326 \mathrm{~kg} / \mathrm{ha}$ ) than control and other lower levels. The integrated nutrient management practices followed in groundnut was found to be significant with respect to pod yield $(2397 \mathrm{~kg} / \mathrm{ha})$ and yield attributing characters than either fully organic or inorganic nutrient management practices. The combined application with biodegradable mulch, hydrogel @5.0 kg/ha and integrated nutrient management practices followed in groundnut proved to be significantly superior with respect to pod yield of groundnut $(2397 \mathrm{~kg} / \mathrm{ha})$, net return of Rs. $54524 \mathrm{Rs}$./ha and benefit cost ratio of 2.40 over other combinations studied.

HOW TO CITE THIS ARTICLE : Patro, H. and Ray, M. (2016).Effect of mulching, hydrogel and nutrient management on productivity of summer groundnut. Asian J. Environ. Sci., 11(2): 156-159, DOI: 10.15740/ HAS/AJES/11.2/156-159.
Author for correspondence :

\section{RAY}

Regional Research and Technology Transfer Station (RRTTS)

(OUAT), KEONJHAR (ODISDHA) INDIA

Email : monikarayouat@ gmail.com

See end of the article for Coopted authors' 